\title{
BERBAGAI KONSENTRASI CMC (Carboxyl Methyl Cellulose) \\ TERHADAP SIFAT FISIKOKIMIA DAN ORGANOLEPTIK \\ SELAI LABU SIAM (Sechium Edule) \\ (Various CMC (Carboxyl Methyl Cellulose) Concentration on the \\ Physicochemical and Organoleptic Test of Chayote Jam)
}

\author{
Endang Bekti ${ }^{1}$, Yuli Prasetyowati ${ }^{2}$, Sri Haryati ${ }^{3}$ \\ ${ }^{1,3}$ Staff Pengajar Teknologi Hasil Pertanian Universitas Semarang \\ ${ }^{2}$ Mahasiswa Teknologi Hasil Pertanian Universitas Semarang \\ yuliprasetyowati726@gmail.com
}

\begin{abstract}
RINGKASAN
Penelitian ini bertujuan untuk mengetahui pengaruh konsentrasi $\mathrm{cmc}$ terhadap sifat kimia (kadar air dan $\mathrm{pH}$ ), sifat fisik (viskositas, daya oles, sineresis) dan organoleptik (warna dan tekstur) selai labu siam. Rancangan percobaan yang digunakan adalah rancangan Acak Kelompok (RAK) satu faktor dengan konsentrasi CMC. Data yang diperoleh dianalisa dengan menggunakan sidik ragam Data dianalisis dengan sidik ragam, dan dilanjutkan uji Beda Nyata Jujur (BNJ) pada taraf 5\%. Hasil yang diperoleh yaitu konsentrasi CMC berpengaruh nyata terhadap $\mathrm{pH}$, viskositas, sineresis serta organoleptik warna dan tekstur tetapi tidak berpengaruh terhadap kadar air. Untuk overall menunjukkan bahwa pada perlakuan P4 (konsentrasi CMC 0,75\%) disukai oleh panelis dengan karakteristik kadar air $9,98 \%$, daya oles $6,11 \mathrm{~mJ}$, viskosita 3590cP dan tekstur 5,2.
\end{abstract}

Kata kunci : Labu Siam, CMC, Selai.

\section{SUMMARY}

This study aims to determine the effect of CMC concentration on chemical properties (water content and $\mathrm{pH}$ ), physical properties (viscosity, topicality, sineresis) and organoleptic (color and texture) of chayote jam. The experimental design used was a one factor Randomized Complete Block Design (RCBD) with a concentration of CMC. The data obtained were analyzed by using vocabulary. If there is a significant difference in influence, then continued with HSD (Honestly Significant Difference) at 5\%. CMC concentration had a significant effect on $\mathrm{pH}$, viscosity, sineresis and organoleptic color and texture but no effect ( $F$ count $<$ Ftabel) to water content. The overalls is the treatment of P4 (concentration CMC $0.75 \%$ ) was favored by panelists with water content characteristics of $9.98 \%$, topicality $6.11 \mathrm{~mJ}$, viscosity $3590 \mathrm{cP}$ and texture 5.2.

Keywords: Chayote, CMC, Jam.

Yuli Prasetyowati. Universitas Semarang. Sukorukun Jaken Pati (59184) 


\section{PENDAHULUAN}

Tanaman labu siam (Sechium edule) termasuk dalam suku labu-labuan yang dapat dikonsumsi bagian buah dan daun pucuk mudanya. Masyarakat Indonesia umumnya menjadikan buah tanaman labu siam sebagai sayuran. Buah tanaman labu siam kaya akan kandungan zat gizi, salah satu nutrisi yang terkandung di dalamnya adalah serat nabati yang termasuk dalam golongan pektin. Serat nabati dapat mengurangi penyerapan kolestrol pada usus serta menurunkan kolestrol darah (Wiadnya, dkk., 2014)

Labu siam mengandung mineral yang cukup tinggi yang memiliki manfaat bagi tubuh apabila dikonsumsi dalam jumlah yang tepat. Mineral merupakan salah satu nutrisi yang dibutuhkan oleh tubuh seperti kalsium dan kalium yang termasuk makromineral. Di dalam tubuh mineral berperan dalam pemeliharaan fungsi tubuh, baik tingkat sel, jaringan, organ, maupun fungsi tubuh keseluruhan. Kalsium memiliki manfaat dalam pembentukan tulang dan gigi sedangkan kalium dapat mengendalikan tekanan darah, terapi darah dan membersihkan karbondioksida pada tubuh (Fitriani, dkk., 2012)

Kandungan serta tinggi manfaat yang dimiliki buah labu siam saat ini hanya diolah menjadi sayuran. Oleh karena itu perlu adanya olahan kreatif dari buah labu siam mengingat manfaat yang dimilikinya agar buah labu siam dapat disukai atau dijangkau oleh semua kalangan, baik anak anak sampai ke yang dewasa. Selain itu juga sebagai alternatif untuk meningkatkan nilai jual dari buah labu siam tersebut. Salah satu inovasi olahan buah labu siam adalah dengan mengolah buah labu siam menjadi selai.

Selai merupakan produk yang dibuat dari buah-buahan yang telah dihancurkan serta dilakukan penambahan gula kemudian dipanaskan atau dimasak sampai terbentuk tekstur kental. Selama ini pengertian selai berbahan baku dari buah-buahan, maka perlu dimodifikasikan dengan bahan lain seperti sayuran buah seperti labu siam. Kriteria mutu selai buah dapat dilihat pada Tabel 2.

\begin{tabular}{lcc}
\multicolumn{2}{l}{ Tabel 2. Syarat Mutu Selai Buah } & \\
\hline Kriteria uji & Satuan & Persyaratan \\
\hline Keadaan & & Normal \\
- Aroma & - & Normal \\
- Warna & - & Normal \\
- Rasa & - & Positif \\
Serat buah & - & min 65 \\
Padatan terlarut & \% Fraksi massa & \\
Cemaran logam & & maks $250,00^{*}$ \\
Timah (5n)* & mg/kg & maks 1,0 \\
Cemaran arsen & mg kg & \\
Cemaran mikroba & & maks. $1 \times 10^{3}$ \\
Angka lempeng total & Koloni/g & $<3$ \\
Bakteri coliform & APMg & maks. $2 \times 10^{3}$ \\
Staphylococcus aureus & Koloni/g & $<10$ \\
Clostrodium & Koloni/g & maks. $2 \times 10^{5}$ \\
Kapang/ khamir & Koloni/g & \\
\hline Sumber: SNI (2008) & &
\end{tabular}

Penelitian ini bertujuan untuk mengetahui pengaruh konsentrasi CMC terhadap sifat fisikokimia dan organoleptik selai buah labu siam. 


\section{METODOLOGI PENELITIAN}

\section{Bahan}

Buah labu siam umur panen \pm 4-5 bulan yang diperoleh dari salah satu kebun di daerah Sumowono, gula pasir "rose brand" dari tebu, asam sitrat, aquades dan larutan buffer.

\section{Alat}

Pisau, talenan, blender, panci, tampah, spatula, kompor, baskom, baskom peniris, timbangan analog, timbangan digital, gelas ukur, kompor gas, sendok, cup plastik, label, alat tulis. Tabung reaksi, botol timbang, timbangan digital, oven, pipet, beaker glass, sendok, gelas piala, eksikator, spindle viskometer brooke, viskometer, $\mathrm{pH}$ meter, elektroda $\mathrm{pH}$, tissue, botol semprot, refraktometer.

\section{Prosedur Penelitian}

Proses pembuatan selai labu siam diawali dengan sortasi buah sesuai umur panen \pm 4-5 bulan. Labu siam dipotong kemudian dibersihkan getahnya dan bijinya dibuang. Kemudian ditimbang sebanyak 1250 gram. Dilakukan pencucian menggunakan air bersih. Setelah itu diblanching dengan suhu $103^{\circ} \mathrm{C}$ selama 3 menit dengan air 500ml. Dihancurkan menggunakan blender dengan ditambahkan air sebanyak $250 \mathrm{ml}$. Kemudian ditambahkan CMC sesuai perlakuan ( $0 \% ; 0,25 \%$ $; 0,50 \% ; 0,75 \% ; 1 \%$ ), asam sitrat $0,3 \%$ dan gula $50 \%$. Dilakukan pemanasan dengan suhu $103{ }^{\circ} \mathrm{C}$ selama 20 menit. Setelah itu didinginkan pada suhu ruang selama 1 jam.

Penelitian ini menggunakan metode Rancangan Acak Lengkap (RAL), adapun formulasi yang ditetapkan dalam perlakuan adalah sebagai berikut.

$\mathrm{P} 1$ : konsentrasi CMC $0 \%$

$\mathrm{P} 2$ : konsentrasi CMC $0,25 \%$

$\mathrm{P} 3$ : konsentrasi CMC 0,50 \%

$\mathrm{P} 4$ : konsentrasi CMC 0,75\%

P5 : konsentrasi CMC 1,00\%

Masing masing perlakuan diulang sebanyak 4 kali, dilanjutkan dengan uji BNJ pada taraf $5 \%$.

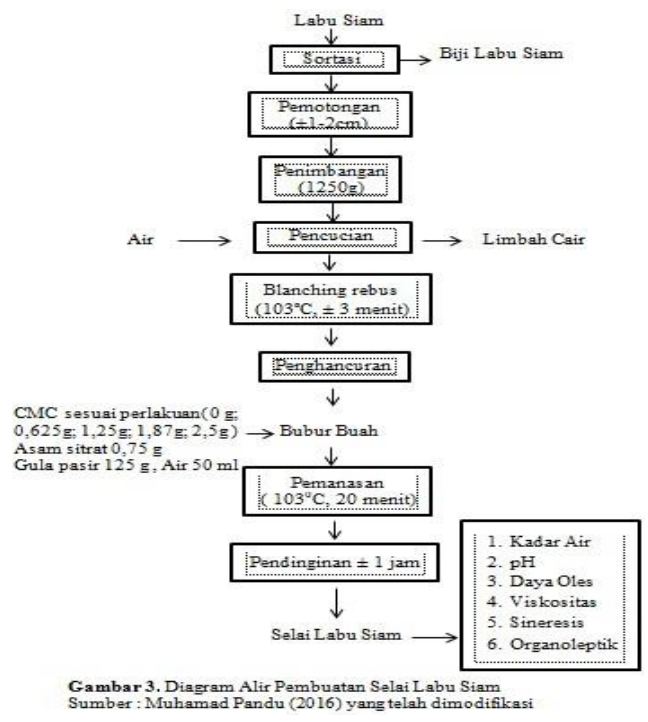




\section{HASIL DAN PEMBAHASAN}

\section{A. Sifat Kimia Selai Labu Siam}

\section{Kadar Air}

Berdasarkan penelitian yang telah dilakukan analisis varian menyatakan tidak ada pengaruh (Fhitung < Ftabel) yang nyata terhadap kadar air selai labu siam. Rerata kadar air selai labu siam adalah sebagai berikut :

Tabel 7. Rerata Kadar Air Selai Labu Siam

\begin{tabular}{lc}
\hline Perlakuan & Rerata hasil \\
\hline P1 (Konsentrasi CMC 0\%) & $11,94^{\mathrm{a}}$ \\
P2 (Konsentrasi CMC 0,25\%) & $11,62^{\mathrm{a}}$ \\
P3 (Konsentrasi CMC 0,50\%) & $10,18^{\mathrm{a}}$ \\
P4 (Konsentrasi CMC 0,70\%) & $9,98^{\mathrm{a}}$ \\
P5 (Konsentrasi CMC 1\%) & $9,54^{\mathrm{a}}$ \\
\hline
\end{tabular}

Semakin banyak konsentrasi CMC yang ditambahkan dapat menurunkan kadar air pada selai labu siam. Kadar air terendah terdapat pada perlakuan P5 dengan nilai 9,54\% dan kadar air terendah terdapat pada perlakuan P1 dengan nilai 11,94\%. Adapun grafik kadar air selai labu siam dapat dilihat pada gambar4.

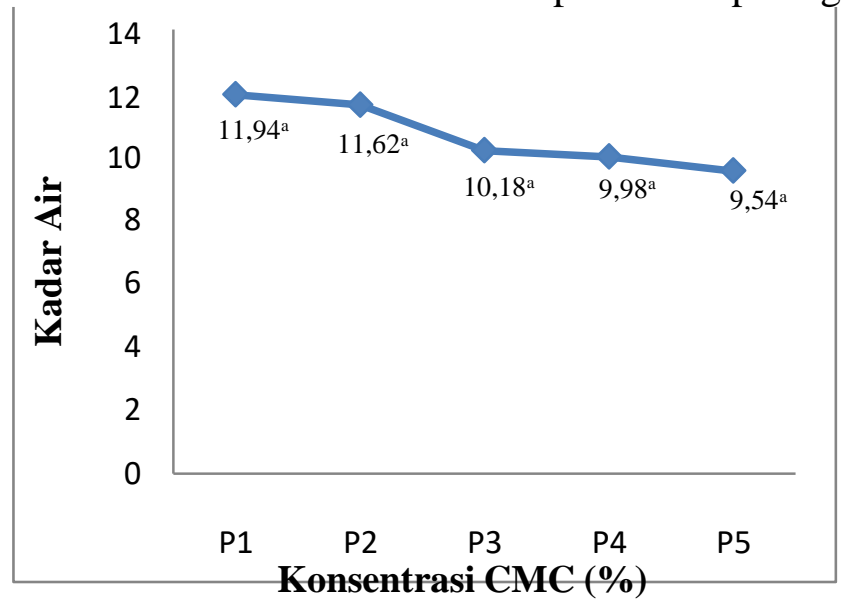

Hasil uji BNJ pada taraf 5\% menunjukkan tidak berbeda nyata. Hal ini disebabkan bahan baku labu siam yang digunakan sama yaitu mengandung pektin sebesar $6,7 \%$. Hal ini diduga karena sifat pektin yang mampu membentuk gel bersama air-gula-asam sehingga air yang ada terperangkap untuk pembentukan gel. Semakin tinggi kadar pektin, maka struktur serabut halus akan semakin padat sehingga pada kandungan pektin yang tinggi akan membentuk gel yang liat (Harris, 1990). Pembentukan gel mengakibatkan air yang ada terperangkap sehingga tingginya kandungan pektin pada labu siam dapat menurunkan kadar air.

Menurunnya kadar air pada selai buah labu siam berkaitan dengan konsentrasi CMC yang diberikan. Semakin konsentrasi CMC maka kadar air yang dihasilkan selai labu siam semakin menurun. Hal ini sesuai dengan pernyataan Minifie (1989) yang menyatakan bahwa CMC merupakan pengental yang mampu mengikat air sehingga molekul air terperangkap dalam struktur gel yang dibentuk oleh CMC. 
Menurut kriteria mutu selai buah SII. No.173 (1978) dalam Fachruddin (1998). Data uji kadar air yang dihasilkan dari beberapa perlakuan pembuatan selai buah labu siam sudah memenuhi syarat, dengan anjuran kadar air maksimum $35 \%$.

\section{Derajat Keasaman (pH)}

Berdasarkan analisis varian menyatakan bahwa penambahan konsentrasi $\mathrm{CMC}$ ada pengaruh yang nyata ( Fhitung > Ftabel) terhadap pH selai labu siam dan diperoleh hasil sebagai berikut:

Tabel 8. Rerata Derajat Keasaman (pH) Selai Labu Siam

\begin{tabular}{cc}
\hline Perlakuan & Rerata hasil \\
\hline P1 (Konsentrasi CMC 0 \% ) & $3,49^{\mathrm{a}}$ \\
P2 (Konsentrasi CMC 0,25\%) & $3,53^{\mathrm{a}}$ \\
P3 (Konsentrasi CMC 0,50\%) & $3,69^{\mathrm{ab}}$ \\
P4 (Konsentrasi CMC 0,70\%) & $3,77^{\mathrm{b}}$ \\
P5 (Konsentrasi CMC 1,00\%) & $3,83^{\mathrm{b}}$ \\
\hline
\end{tabular}

Hasil analisa uji BNJ taraf 5\% menunjukkan adanya perbedaan yang nyata terhadap derajat keasaman $(\mathrm{pH})$. Berikut derajat keasaman $(\mathrm{pH})$ selai labu siam dapat dilihat pada Gambar 5.

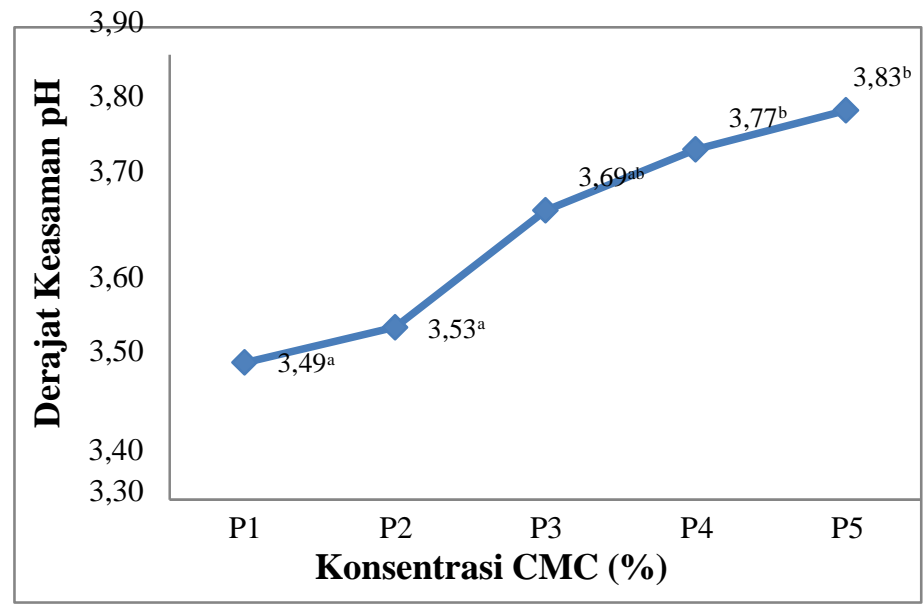

Hasil analisis menunjukkan bahawa perlakuan P1 berbeda nyata dengan perlakuan P4 dan P5 akan tetapi tidak berbeda nyata pada perlakuan P2 dan P3. $\mathrm{pH}$ tertinggi adalah 3,83 yang ditunjukkan dari hasil analisis selai buah labu siam perlakuan P5 dengan konsentrasi CMC 1\%. Sedangkan pH terendah adalah 3,49 yang ditunjukkan dari hasil analisis selai buah labu siam perlakuan P1 dengan konsentrasi CMC $0 \%$. Menurut Buckle (1985) kondisi optimum untuk pembentukan gel pada selai adalah asam $\mathrm{pH} 3,2-3,4 \%$. Pada adonan selai labu siam terdapat $\mathrm{pH}$ asam, $\mathrm{pH}$ yang terkandung dalam adonan labu siam sekitar 3,33,83 .

Peningkatan $\mathrm{pH}$ tersebut disebabkan CMC mengandung gugus karboksil dan mudah terhidrolisis sehingga dapat meningkatkan $\mathrm{pH}$. Gugus karboksil 
memberikan sifat asam. Peningakatan $\mathrm{pH}$ tersebut sesuai dengan pernyataan Wayan (2009) yang menyatakan bahwa semakin tinggi persentase CMC yang diberikan pada bahan maka semakin tinggi gugus karboksil yang terhidrolisis sehingga nilai $\mathrm{pH}$ semakin meningkat.

\section{B. Sifat Fisik Selai Labu Siam}

\section{Viskositas}

Berdasarkan analisis varian bahwa penambahan konsentrasi CMC menyatakan adanya pengaruh yang nyata ( Fhitung > Ftabel) terhadap viskositas selai labu siam dan diperoleh hasil sebagai berikut :

Tabel 9. Rerata Viskositas Selai Labu Siam

\begin{tabular}{ll}
\hline \multicolumn{1}{c}{ Perlakuan } & Rerata hasil (cP) \\
\hline P1 (Konsentrasi CMC 0 \%) & $2185^{\mathrm{a}}$ \\
P2 (Konsentrasi CMC 0,25\%) & $2275^{\mathrm{a}}$ \\
P3 (Konsentrasi CMC 0,50\%) & $3225^{\mathrm{b}}$ \\
P4 (Konsentrasi CMC 0,70\%) & $3590^{\mathrm{b}}$ \\
P5 (Konsentrasi CMC 1,00\%) & $4665^{\mathrm{c}}$ \\
\hline
\end{tabular}

Hasil uji BNJ pada taraf 5\% menunjukkan perbedaan yang nyata terhadap viskositas. Perlakuan P1 berbeda nyata terhadap perlakuan P3, p4 dan P5. Kekentalan tertinggi yakni pada perlakuan P5 konsentrasi CMC 1\% dengan nilai $4665 \mathrm{cP}$. Sedangkan kekentalan terendah terdapat pada perlakuan P1 konsentrasi CMC $0 \%$ yaitu dengan nilai $2185 \mathrm{cP}$.

Menurut Antarlina dan Ginting (1992) faktor yang mempengaruhi viskositas, antara lain kadar air bahan. Analisis viskositas dilakukan menggunakan alat viscometer brookfield. Viskositas selai labu siam dapat dilihat pada Gambar 6 berikut ini.

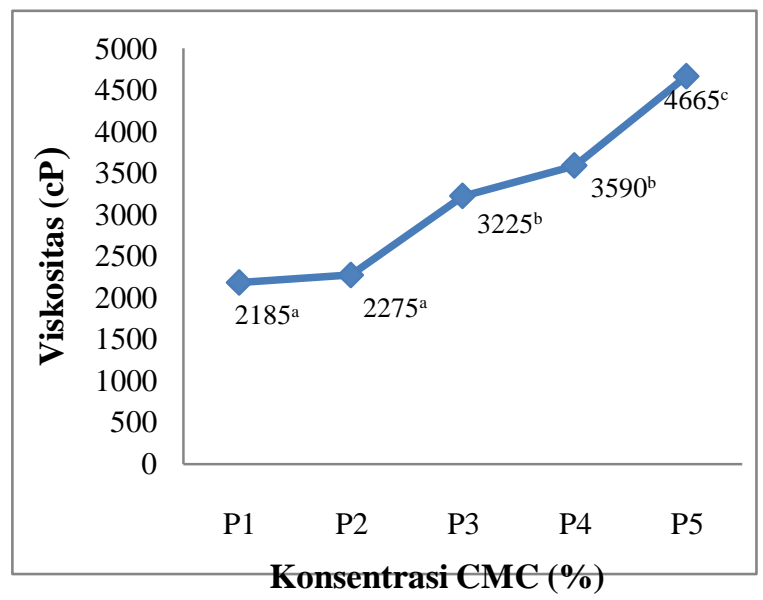

Faktor yang mempengaruhi pembentukan gel dengan tingkat kekentalan dan kekuatan selai buah labu siam meliputi $\mathrm{pH}$, konsentrasi pektin, suhu, ion, kalsium, dan gula (Chang dan Miyamoto, 1992). Labu siam (Sechium edule) merupakan tanaman yang potensial untuk dikembangkan sebagai sumber pektin. Buahnya mengandung pektin sebesar 2,7 - 6,7\% (Kertesz, 1951). Pektin pada labu siam 
akan mengalami gelatinisasi pada waktu dipanaskan sehingga mengakibatkan terjadinya peningkatan viskositas.

Pengukuran viskositas berdasarkan tingkat kekentalan yang dimiliki selai labu siam pada setiap perlakuan, dengan indikasi kecepatan putaran spindle. Semakin lambat putaran spindle semakin kental selai buah labu siam, dengan ditunjukkan nilai viskositas yang tinggi. Rendahnya penambahan CMC akan menghasilkan selai labu siam yang encer. Sementara tingginya penambahan CMC akan menghasilkan selai labu siam yang kental.

Hal ini sesuai dengan pernyataan Fennema, dkk. (1996) yang menyatakan bahwa CMC yang bersifat hidrofilik akan menyerap air dimana air yang sebelumnya ada di luar granula dan bebas bergerak, tidak dapat bergerak lagi dengan bebas sehingga keadaan larutan lebih mantap dan terjadi peningkatan viskositas.

\section{Daya Oles}

Berdasarkan analisis varian bahwa penambahan konsentrasi CMC menyatakan adanya pengaruh yang nyata (Fhitung > Ftabel) terhadap daya oles selai labu siam dan diperoleh hasil sebagai berikut:

Tabel 10. Rerata Daya Oles Selai Labu Siam

\begin{tabular}{cc}
\hline Perlakuan & Rerata hasil \\
\hline P1 (Konsentrasi CMC 0 \% ) & $2,31^{\mathrm{a}}$ \\
P2 (Konsentrasi CMC 0,25\%) & $3,05^{\mathrm{a}}$ \\
P3 (Konsentrasi CMC 0,50\%) & $5,38^{\mathrm{b}}$ \\
P4 (Konsentrasi CMC 0,70\%) & $6,11^{\mathrm{b}}$ \\
P5 (Konsentrasi CMC 1,00\%) & $7,48^{\mathrm{b}}$ \\
\hline
\end{tabular}

Tabel 10. menunjukkan bahwa daya oles selai labu siam berkisar antara 2,31 - 748. Pada perlakuan P1 berbeda nyata dengan P3, P4 dan P5 tetapi tidak berbeda nyata dengan P2. Perlakuan P2 berbeda nyata dengan P3, P4 dan P5. Sedangkan perlakuan P3, P4 dan P5 tidak berbeda nyata. Semakin tinggi nilai daya oles, maka selai akan semakin kental dan sulit untuk dioleskan. Berikut grafik daya oles selai labu siam dapat dilihat pada gambar 7 .

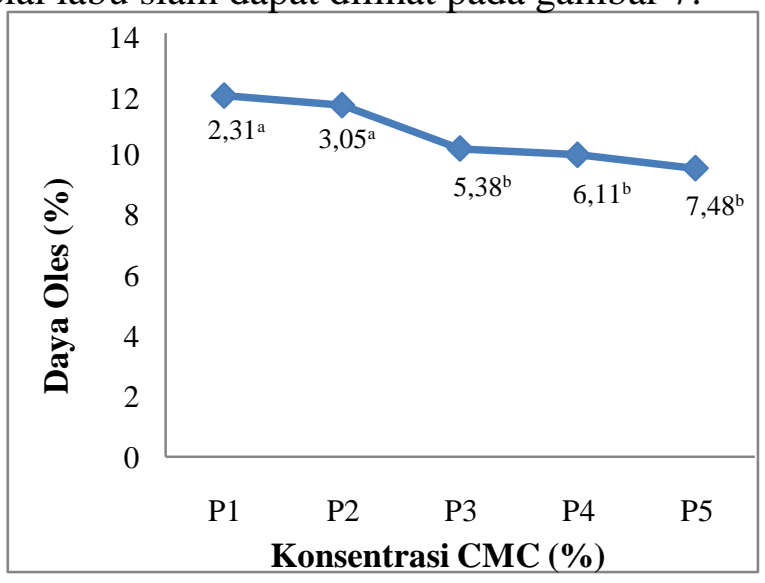


Daya oles berkaitan dengan viskositas yaitu terbentuknya gel. Pada uji viskositas dikatakan semakin tinggi penambahan CMC maka selai labu siam yang dihasilkan akan semakin kental artinya jika selai buah labu siam terlalu kental maka tidak mudah untuk dioleskan, begitu juga jika penambahan CMC terlalu rendah maka selai buah labu siam akan encer, artinya daya oles tidak akan melekat baik pada roti. Hal ini sesuai dengan pernyataan Fennema, dkk. (1996) yang menyatakan bahwa CMC yang bersifat hidrofilik akan menyerap air dimana air yang sebelumnya ada di luar granula dan bebas bergerak, tidak dapat bergerak lagi dengan bebas sehingga keadaan larutan lebih mantap dan terjadi peningkatan viskositas.

Gel yang kurang akan menyebabkan daya oles menjadi kurang dimana selai akan terlihat encer sedangkan gel yang terlalu keras akan menyebabkan selai menjadi keras sehingga akan sulit dioleskan.

\section{Sineresis}

Berdasarkan analisis varian bahwa konsentrasi CMC menyatakan adanya pengaruh yang nyata (Fhitung > Ftabel) terhadap sineresis selai labu siam dan diperoleh hasil sebagai berikut:

Tabel 11. Rerata Sineresis Selai Labu Siam

\begin{tabular}{ll}
\multicolumn{1}{c}{ Perlakuan } & Rerata hasil \\
\hline P1 (Konsentrasi CMC 0 \%) & $5,39^{\mathrm{a}}$ \\
P2 (Konsentrasi CMC 0,25\%) & $3,93^{\mathrm{ab}}$ \\
P3 (Konsentrasi CMC 0,50\%) & $1,72^{\mathrm{bc}}$ \\
P4 (Konsentrasi CMC 0,70\%) & $1,08^{\mathrm{c}}$ \\
P5 (Konsentrasi CMC 1,00\%) & $0,96^{\mathrm{c}}$ \\
\hline
\end{tabular}

Tabel 11 menunjukkan bahwa sineresis selai labu siam berkisar antara 0,96 - 5,39 \%. Sineresis tertinggi terdapat pada perlakuan P1 yaitu 5,39\% dan sineresis terendah terdapat pada perlakuan P5 yaitu $0,96 \%$. Pada uji lanjut BNJ menunjukkan bahwa P1 berbeda nyata dengan P2, P3, P4 dan P5. Perlakuan P2 berbeda nyata dengan P3, P4 dan P5. Perlakuan P3 berbeda nyata dengan P4 dan P5. Sedangkan P4 tidak berbeda nyata dengan P5. Kadar sineresis mengalami beda nyata hal ini dikarenakan kadar air yang terdapat pada selai. Sineresis yang semakin tinggi disebabkan oleh kadar air yang semakin tinggi. Hal ini didukung oleh pernyataan winarno (2004) yang menyatakan bahwa selama penyimpanan terjadi proses sineresis pada gel yang mengakibatkan semakin lama penyimpanan yang dilakukan akan menyebabkan kadar air pada selai semakin tinggi. Berikut sineresis selai labu siam dapat dilihat pada Gambar 8. 


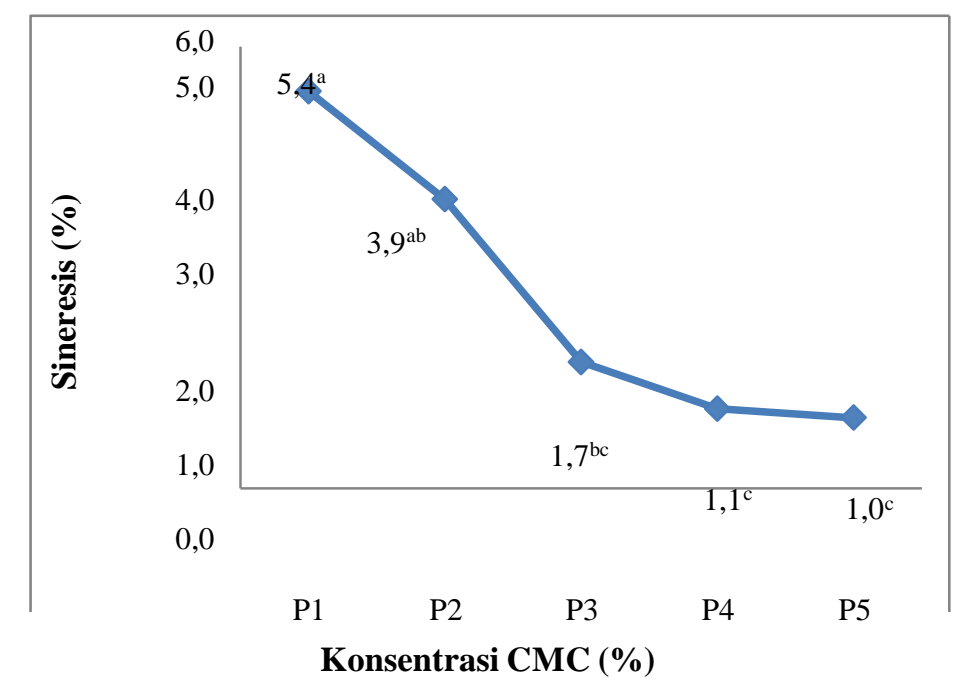

Gambar 8 menunjukkan bahwa sineresis tertinggi terdapat pada perlakuan P1 dengan konsentrasi CMC 0\% yaitu 5,4\%, sedangkan terendah pada perlakuan P5 dengan konsentrasi CMC $1 \%$ yaitu $1,0 \%$. Sineresis pada selai labu siam menurun seiring dengan penambahan CMC. Hal ini dikarenakan kadar air pada selai labu siam menurun sehingga berpengaruh terhadap sineresis yang dihasilkan oleh selai labu siam.

Jumlah presentase sineresis pada selai labu siam yang sedikit juga disebabkan oleh $\mathrm{pH}$ yang terdapat pada selai labu siam yang asam. $\mathrm{pH}$ yang terlalu rendah dapat menyebabkan sineresis yaitu keluarnya air dari dalam gel pada suhu refrigerator. $\mathrm{pH}$ yang terlalu tinggi dapat menyebabkan gel pecah (Winarno, 1989). Selai dengan $\mathrm{pH}$ terlalu asam dapat menyebabkan keluarnya air dari gel (sineresis) (Abdul,2016).

Lama penyimpanan memberikan pengaruh berbeda sangat nyata terhadap uji sineresis. Semakin lama penyimpanan maka uji sineresis menunjukan garis regresi yang cenderung menurun. Hal ini karena kadar air meningkat selama penyimpanan menyebabkan uji sineresis akan semakin menurun. Hal ini dikarenakan selama penyimpanan terjadi proses sineresis pada selai, semakin lama selai yang disimpan maka tekstur selai akan semakin lembek karena meningkatnya kadar air. Proses sineresis adalah keluarnya atau merembesnya cairan dari suatu gel (Winarno, 2004).

\section{Uji Organoleptik Selai Labu Siam}

\section{Uji Organoleptik Warna}

Berdasarkan analisis varian bahwa penambahan konsentrasi CMC menyatakan adanya pengaruh yang nyata (Fhitung > Ftabel) antar perlakuan dan setelah dilakukan uji dengan BNJ pada taraf $5 \%$ menunjukkan perbedaan yang nyata terhadap warna sehingga diperoleh hasil sebagai berikut: 
Tabel 12. Rerata Mutu Hedonik Warna Selai Labu Siam

\begin{tabular}{ccc}
\hline Perlakuan & Rerata hasil & Kriteria \\
\hline P1 (Konsentrasi CMC 0 \%) & $2,2^{\mathrm{a}}$ & Sangat Tidak Cerah-Tidak \\
Cerah \\
P2 (Konsentrasi CMC 0,25\%) & $3.3^{\mathrm{ab}}$ & Tidak Cerah-Agak Cerah \\
P3 (Konsentrasi CMC 0,50\%) & $4.4^{\mathrm{bc}}$ & Agak Cerah-Cerah \\
P4 (Konsentrasi CMC 0,70\%) & $5.1^{\mathrm{cd}}$ & Cerah-Sangat Cerah \\
P5 (Konsentrasi CMC 1,00\%) & $5.8^{\mathrm{d}}$ & Cerah-Sangat Cerah \\
\hline
\end{tabular}

Hasil analisis statistik menunjukkan bahwa perlakuan konsentrasi CMC memberi pengaruh nyata terhadap warna selai labu siam. Hasil uji lanjut BNJ taraf 5\% terhadap warna selai labu siam berbeda nyata. Hal ini sesuai dengan teori Winarno (1997) reaksi pencoklatan non-enzimatik dapat terjadi dalam bahan pangan akibat reaksi karamelisasi gula dan reaksi maillard yaitu reaksi antara gula dan asam amino selama pemanasan. Hal ini menggambarkan bahwa meningkatnya jumlah konsentrasi CMC berpengaruh terhadap skor warna selai labu siam. Berikut grafik organoleptik warna selai buah labu siam disajikan pada Gambar 9.

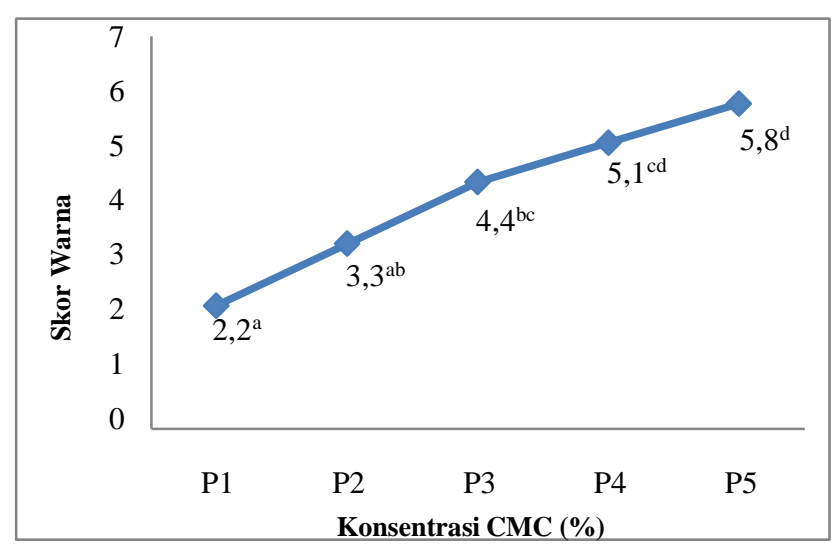

Semakin tinggi jumlah CMC yang ditambahkan pada bubur labu siam, warna selai labu siam semakin meningkat. Hal tersebut disebabkan oleh adanya penambahan hidrokoloid yang dapat menyerap air dan kemampuan CMC yang dapat menahan oksidasi warna yang ada pada selai labu siam selama pengolahan. Semakin banyak CMC yang ditambahkan pada perlakuan, maka nilai warna semakin rendah dan kepudaran warna semakin tinggi (Anggraini, dkk., 2012)

\section{Uji Organoleptik Tekstur}

Berdasarkan analisa sidik ragam ANOVA menunjukkan bahwa konsentrasi CMC pada selai labu siam berpengaruh nyata terhadap mutu hedoniktekstur, yang dapat diketahui dari nilai $\mathrm{F}_{\text {hitung }}>\mathrm{F}_{\text {tabel }}$. Setelah dilakukan uji lanjut BNJ taraf 5\% semua perlakuan berbeda nyata terhadap mutu hedonik kekenyalan. Hasil uji mutu hedonik tekstur konsentrasi CMC selai labu siam dapat dilihat pada Tabel 13 
Tabel 13. Rerata Mutu Hedonik Tekstur Selai Labu Siam

\begin{tabular}{ccc}
\hline Perlakuan & Rerata hasil & Kriteria \\
\hline P1 (Konsentrasi CMC 0 \%) & $1,7^{\mathrm{a}}$ & $\begin{array}{c}\text { Amat Sangat Tidak Kental - } \\
\text { Sangat Tidak Kental }\end{array}$ \\
P2 (Konsentrasi CMC 0,25\%) & $3,3^{\mathrm{b}}$ & Tidak Kental - Agak Kental \\
P3 (Konsentrasi CMC 0,50\%) & $4^{\mathrm{b}}$ & Agak Kental \\
P4 (Konsentrasi CMC 0,70\%) & $5,1^{\mathrm{c}}$ & Kental - Sangat Kental \\
P5 (Konsentrasi CMC 1,00\%) & $6,4^{\mathrm{d}}$ & Sangat Kental - Amat Sangat \\
& & Kental \\
\hline
\end{tabular}

Tabel 13. menunjukkan bahwa nilai mutu hedonik tekstur selai labu siam berkisar antara 1,7 - 6,4. Pada perlakuan P1 berbeda nyata dengan P2, P3, P4 dan $\mathrm{P} 5$. Perlakuan $\mathrm{P} 2$ berbeda nyata dengan $\mathrm{P} 3$ dan $\mathrm{P} 4$ tetapi tidak berbeda nyata dengan P3. Perlakuan P3 berbeda nyata dengan P4 dan P5. Perlakuan P4 berbeda nyata dengan P5. Perbedaan tekstur disebabkan oleh perbedaan penambahan konsentrasi CMC tiap perlakuan dalam pembuatan selai. Berikut grafik mutu hedonik tekstur selai labu siam dapat dilihat pada gambar 10 .

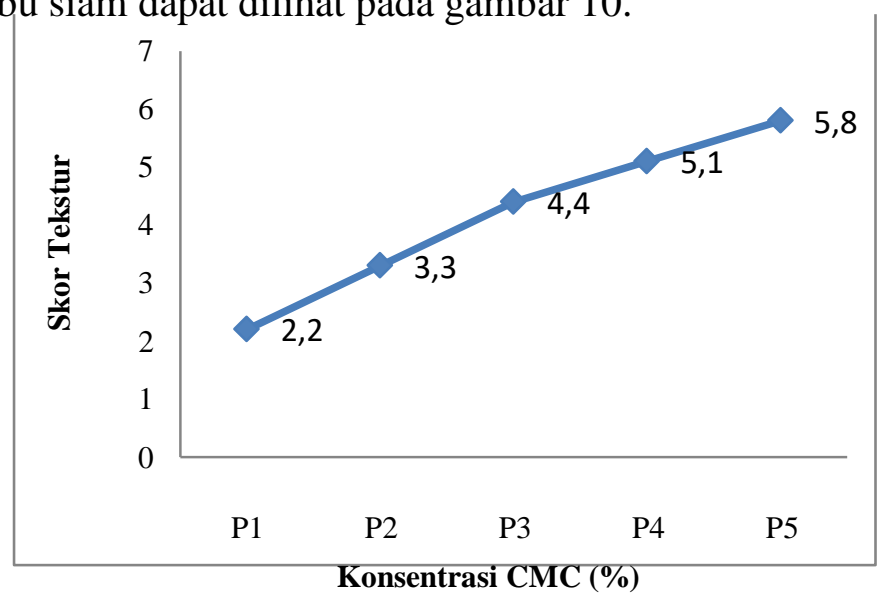

Semakin tinggi konsentrasi CMC yang ditambahkan pada selai labu siam maka nilai mutu hedonik tekstur akan meningkat. Peningkatan nilai skor tekstur tersebut dikarenakan viskositas dari selai meningkat sehingga tekstur yang dihasilkan lebih mantap dan kental. Hal ini sesuai dengan pernyataan Fennema, dkk. (1996) yang menyatakan bahwa CMC yang bersifat hidrofilik akan menyerap air yang sebelumnya ada di luar granula dan bebas bergerak, tidak dapat bergerak lagi dengan bebas sehingga keadaan larutan lebih mantap dan terjadi peningkatan viskositas. Peningkatan kekentalan ini juga terjadi karena CMC yang ditambahkan memiliki kemampuan mengikat air, sehingga molekul-molekul air terperangkap dalam tekstur gel yang dibentuk. Keadaan ini didukung oleh pendapat Ganz (1997) yang menyatakan bahwa CMC memiliki sifat ionik $\mathrm{Na}^{+} \mathrm{CMC}$ yang dapat menarik partikel-partikel endapan yang terdapat dalam selai labu siam sehingga dapat membentuk struktur gel dan meningkatkan kekentalan. 


\section{KESIMPULAN DAN SARAN}

\section{A. Kesimpulan}

Hasil penelitian menunjukkan bahwa konsentrasi CMC pada selai labu siam menunjukkan adanya pengaruh yang nyata (Fhitung > Ftabel) terhadap pH, viskositas, sineresis, daya oles, uji organoleptik warna dan uji organoleptik tekstur tetapi tidak berpengaruh terhadap kadar air.

Perlakuan terbaik dari parameter yang telah diuji adalah P4 (konsentrasi CMC 0,75\%), dengan kadar air 9,98\% yang telah memenuhi SNI 3746: 2008 , pH $3,77 \%$, viskositas $3590 \mathrm{cP}$, sineresis $1,08 \%$ dan daya oles 6,11 . Hasil uji sensori secara mutu hedonik perlakuan P4 mendapatkan skor atribut warna 5,1 (cerah) dan tekstur 5,1 (kental)

\section{B. Saran}

1. Perlu ditambahkan beberapa bahan tambahan pangan lain, terutama bahan pengawet yang aman sehingga dapat meningkatkan daya awet selai labu siam.

2. Perlu dilakukan penelitian lanjut mengenai daya simpan selai serta penelitian mengenai cara menghambat sineresis pada selai labu siam.

\section{DAFTAR PUSTAKA}

Buckle, K.A., R.A. Edwards, G.H. Fleet dan M. Wootton. 1985. Ilmu Pangan. Penerjemah: Hari Purnomo dan Andiono. UI.Press, Jakarta.

Fachruddin. 1997. Membuat Aneka Selai. Yogyakarta: Kanisius.

Fennema, O., Karen, M., dan Lund, D., 1996.Principle of Food Science.The AVI Publishing, Connecticut.

Harris, P. 1990. Food Gels. Elsevier Science. New Yrk. 401-427 pp

Minifie, B. W., 1989. Chocolate, Cocoa, and Confectionery. Van Nostrand Reinhold, New York.

Wiadnya, I. B. R. S. zaetun, dan W. L. Lina. 2014. Efektivitas Pemberian Filtrat Labu Siam (Sechium edule) Terhadap Penurunan Kadar Kolesterol Total pada Darah Hewan Coba Tikus (Ratus noruegius) Atrain Wistar. Jurnal Media Bina Ilmiah. 8(1): 50-51.

Wayan, 2009. Karboksimetil selulosa (CMC).http://wayan.web.id[21 Februari 2018]

Winarno, F. G. 1992. Kimia Pangan dan Gizi. Gramedia Pustaka Utama, Jakarta. 